the snow went in the spring, Major Williams was able to find his plugs and to identify some of them, with the result that he sent this table to Dr. Hutton.

\begin{tabular}{|c|c|c|c|c|c|}
\hline Time & & $\begin{array}{l}\text { Therm } \\
{\left[{ }^{\circ} \mathrm{F} .\right]}\end{array}$ & Elev. of the Fuze & $\begin{array}{l}\text { Weight of Plug } \\
\text { [ounces] }\end{array}$ & Distance \\
\hline 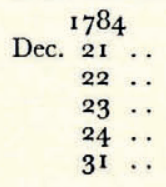 & $\begin{array}{l}\cdots \\
\cdots \\
\cdots \\
\cdots\end{array}$ & $\begin{array}{l}-10 \\
-\quad 3 \\
-16 \\
-6 \\
-18\end{array}$ & $\begin{array}{l}90 \\
90 \\
90 \\
80 \\
45\end{array}$ & $\begin{array}{l}35 \\
37 \cdot 25 \\
34 \cdot 5 \\
39 \cdot 25 \\
39 \cdot 25\end{array}$ & $\begin{array}{c}\text { Unknown } \\
22 \text { feet } \\
\text { Unknown } \\
62 \\
3^{87}\end{array}$ \\
\hline $\begin{array}{r}\begin{array}{r}1785 \\
\text { Jan. } \\
2\end{array} \\
4 \\
9\end{array}$ & $\begin{array}{l}\cdots \\
\cdots \\
\cdots\end{array}$ & $\begin{array}{l}-19 \\
-12 \\
-\quad 4\end{array}$ & $\begin{array}{l}45 \\
45 \\
45\end{array}$ & $\begin{array}{l}4^{1} \cdot 75 \\
4^{2} \\
4^{0} \cdot 5\end{array}$ & $\begin{array}{l}415 \\
\text { Burst } \\
325\end{array}$ \\
\hline
\end{tabular}

The true spirit of inquiry is surely reflected in this simple table, as all who have had to work outside in sub-zero weather (even with modern clothing and conveniences) will appreciate.

Robert F. Legget

\title{
THE POSITION OF MARKERS ON THE GREENLAND ICE SHEET
}

\author{
By W. S. B. Paterson \\ (Surveyor, British North Greenland Expedition 1952-54)
}

The positions of seven markers, erected on the Greenland Ice Sheet were accurately determined by members of the British North Greenland Expedition 1952-54. In three cases the height of a fixed mark above the snow surface was measured. It is hoped that in a decade or two these will be found by future expeditions and their heights redetermined so as to enable a measurement to be made of the rate of movement of the ice sheet and the net accumulation.

The following information about the markers is published for future reference. The probable error in altitude is $10 \mathrm{~m}$. in all cases, and the probable errors are $0 \cdot \mathrm{I}^{\prime}$ in latitude and 0.5 ' in longitude except in the case of A.r9 and "Northice".

B.9. Position: lat. $77^{\circ} 19.4^{\prime} \mathrm{N}$., long. $27^{\circ} 55.5^{\prime} \mathrm{W}$. Altitude $17 \mathrm{I} 3 \mathrm{~m}$. The marker is an open square pyramid with an aluminium sheet as top mark. The lowest of the top screws was $7 \cdot 9 \mathrm{~m}$. above the snow surface on I May 1954.

A. I4. Position: lat. $77^{\circ} 27 \cdot 7^{\prime}$ N., long. $29^{\circ} 03 \cdot 8^{\prime}$ W. Altitude $1812 \mathrm{~m}$. The marker is an iron pipe about $15 \mathrm{~cm}$. diameter.

A. 19. Position: lat. $77^{\circ} 30^{\prime}$ o $\mathrm{I}^{\prime \prime}$ N., long. $30^{\circ} 10^{\prime} 43^{\prime \prime}$ W. Altitude $1878 \mathrm{~m}$. Probable error $3^{\prime \prime}$ in latitude, $12^{\prime \prime}$ in longitude. Marker similar to B.9. The upper screw at the apex was $7 \cdot 9 \mathrm{~m}$. above the snow surface on 3 May 1954.

B.32. Position: lat. $77^{\circ} 4 \mathrm{I} \cdot 5^{\prime} \mathrm{N}$., long. $33^{\circ} 32 \cdot 5^{\prime} \mathrm{W}$. Altitude $2 \mathrm{r} 20 \mathrm{~m}$. The marker is a pole $12 \mathrm{~cm}$. diameter with an orange box as top mark.

"Northice." Position: lat. $78^{\circ} \mathrm{O}^{\prime}{ }^{\prime} 6^{\prime \prime}$ N., long. $3^{\circ} 29^{\prime} 25^{\prime \prime}$ W. Altitude $2345 \mathrm{~m}$. The marker is the lattice anemometer mast. The top cross-bar was $9^{\circ} \mathrm{I} \mathrm{m}$. above the snow surface in June, 1953.

B.73. Position: lat. $78^{\circ}$ or $\cdot \mathrm{I}^{\prime} \mathrm{N}$., long. $45^{\circ} 47^{\circ} \mathrm{o}^{\prime} \mathrm{W}$. Altitude $25^{\mathrm{I}} 4 \mathrm{~m}$. A pole with canvas top mark.

B.r 1 2. Position: lat. $77^{\circ} 23 \cdot 8^{\prime}$ N., long. $49^{\circ} 26 \cdot 0^{\prime}$ W. Altitude $2530 . \mathrm{m}$. A pole. 